Article

\title{
Riverbed Changes of the Uppermost Atchafalaya River, USA-A Case Study of Channel Dynamics in Large Man-Controlled Alluvial River Confluences
}

\author{
Bo Wang ${ }^{1}$, Y. Jun Xu ${ }^{1,2, *}$, Wei Xu ${ }^{1,3}$, Heqin Cheng ${ }^{3}$, Zhongyuan Chen ${ }^{3}$ and Weiguo Zhang ${ }^{3}$ \\ 1 School of Renewable Natural Resources, Louisiana State University Agricultural Center, Baton Rouge, \\ LA 70803, USA; bwang13@tigers.lsu.edu (B.W.); xuwei930608@163.com (W.X.) \\ 2 Coastal Studies Institute, Louisiana State University, Baton Rouge, LA 70803, USA \\ 3 State Key Lab of Estuarine \& Coastal Research, East China Normal University, Shanghai 200062, China; \\ hqch@sklec.ecnu.edu.cn (H.C.); z.chen@sklec.ecnu.edu.cn (Z.C.); wgzhang@sklec.ecnu.edu.cn (W.Z.) \\ * Correspondence: yjxu@lsu.edu
}

Received: 26 June 2020; Accepted: 27 July 2020; Published: 29 July 2020

\begin{abstract}
River confluences are important nodes for downstream sediment transport and geomorphological development. Previous studies have established the knowledge that under natural conditions, river confluence zones experience channel scour followed with middle channel bar development. Less care is however given to the intensity of a confluence scour zone under man-controlled conditions, such as discharge regulation and levee confinement. In general, our knowledge about long-term bed evolution downstream of large alluvial river confluences is limited. Here we conducted a study focused on the $69-\mathrm{km}$ uppermost channel of the Atchafalaya River, the largest distributary of the Mississippi River, to test the hypothesis that the channel downstream of two large tributaries sustains longer-term, extensive bed scouring owing to increased discharge in the main channel and, therefore, mid-channel bars in such a confluence zone cannot be built under confined channel conditions. The Atchafalaya River carries the total flow from the Red River and approximately 25\% of the Mississippi River flow, traveling southwards $230 \mathrm{~km}$ before emptying into the Gulf of Mexico. We utilized long-term records on water surface elevation and discharge during 1935-2016, as well as channel bathymetry survey data during 1998-2006 to determine changes in hydraulic head and morphologic deformation in the confluence zone. The results from this study show that the combined flow from the Red River and Mississippi River into the Atchafalaya River steadily increased to approximately 5848 cubic meters per second $\left(\mathrm{m}^{3} \mathrm{~s}^{-1}\right)$ in the recent decades, and the channel bed of the uppermost Atchafalaya River experienced considerable erosion since the 1930s. At a specific discharge of $8000 \pm 100 \mathrm{~m}^{3} \mathrm{~s}^{-1}$, the river stage decreased by $5.8,5.6$, and $4.9 \mathrm{~m}$ from 1935 to 2016 at (from upstream to downstream) Simmesport, Melville, and Krotz Springs gauging stations, respectively. The average bed elevation reduced by $1.9 \mathrm{~m}$ from 1998 to 2006, although its thalweg increased by $0.3 \mathrm{~m}$. Based on the channel bed assessment, a total volume of $6.6 \times 10^{7} \mathrm{~m}^{3}$ sediment was eroded from the uppermost $69 \mathrm{~km}$ of the Atchafalaya over the 8 years. The findings suggest that confluence zones of large alluvial rivers under controlled flow and confined levee conditions can experience extensive, long-lasting channel erosion. This can be especially progressive if the channel below a confluence is confined by levees, which can increase drag forces and prevent middle channel deposition. Further studies are needed to determine if the eroded sediment from the uppermost Atchafalaya is carried out to the river mouth or is deposited in the lower Atchafalaya. Such knowledge will have both scientific and practical relevance in river engineering and management.
\end{abstract}

Keywords: river confluence zone; channel dynamics; bed material load; sediment transport; fluvial geomorphology; Mississippi River Delta 


\section{Introduction}

River confluences are important nodes in riverine systems for sediment transport, morphological changes, and pollutant mixing processes [1-4]. Downstream river confluences, morphological changes of the riverbed are crucial for understanding sediment transport, channel dynamics, and floodplain development. Confluences have been extensively studied in their morphological components [3,5-7], flow structures [8-11], sediment transport [12-15], and floodplain evolution around them [16,17]. However, most of these studies were conducted at the confluences of relatively undisturbed, small streams and rivers, and the nature of the studies was often short term. Studies focusing on the engineered confluence of large rivers are rather sparse.

According to Best [6], avalanche faces-a deep central scour with a mid-channel bar-are basic morphological elements downstream of a river confluence. Confluence scours are crucial in terms of downstream sediment transport, bar construction, and channel migration [18], affecting channel stability. They also play a role in flood routing because they could substantially change flow capacity downstream of the confluences [2]. In river engineering, confluence scour is an important factor to consider in the design and maintenance of structures such as bridges and buried pipeline crossings [3]. It has been reported that the confluence angle and the ratio of discharges between the tributaries mainly control the bed morphology downstream confluences, although sediment load could merely modify their effects $[1,3,4,13]$. The scour could deepen with increased confluence angle and discharge ratio between the tributary and main channels, while the scour depth decreases with increased sediment loads $[1,13]$. The scour depth was reported that can be as high as six times the ambient depths in the anabranches [3]. Although scour depth was well studied, little attention has been given to scour length under significantly varied tributary discharge ratio.

Ashworth [19] developed a model to interpret the growth of a mid-channel bar downstream a naturally formed river confluence by the observations of a series of flume experiments $[1,18,20]$. The initial mid-channel bar deposition is related to the distribution of kinetic energy which leads to a downstream reduction in the vertical energy gradient and therefore results in a zone for sediment deposition [21]. This zone is usually a few channel widths downstream of the confluence. The stabilization of the mid-channel bar occurs when the two distributaries around the bar take over from the bartop as the principal corridors for bedload transport [20]. In his flume experiment, Ashworth [19] reported that the bar growth is always accompanied by bank retreat (usually a doubled initial channel width) but negligible distributary incision. However, it is not clear what could happen with a well-confined channel. Would a mid-channel bar form downstream of the scour hole in a large river system?

Channels of alluvial rivers are mainly shaped by water discharge and sediment load. For the factor of sediment load, a significant decrease of sediment delivery to the channel could result in channel bed erosion due to the expending of excess stream power [22]. Numerous studies reported degraded riverbed downstream of dams due to reduced sediment fluxes [23-26]. In terms of water discharge, Everitt [27] found that a profound decline in discharge may cause downstream sediment deposition and shrink of the channel. Pizzuto [28] investigated 16-year channel adjustments to varying discharges in a small meandering river. He reported that the channel expanded by bank erosion during the years with higher discharges. Although channel responses to varied flow and sediment load were well studied, the long-term responses of flow increase on downstream bed morphology in large sand-bed rivers with intense human disturbances are poorly understood. Latimer and Schweizer [29] and Mossa [30] studied changes in channel geometry of the Atchafalaya River. The river is a great interest to fluvial geomorphologists investigating in bed deformation downstream of a large confluence because it is the largest distributary of the Mississippi River and was highly disturbed by human activities and engineering practices since the 1880s. In this study, we investigated the long-term (1935-2016) changes in hydraulic head and riverbed morphology of a levee-confined 69-km channel (the uppermost Atchafalaya River) downstream of a large man-controlled confluence. Three research questions organize this study: (1) how riverbed downstream of a large confluence has changed after 
a long-term increase of tributary inflow by human intervention? (2) If confluence scour in such an engineering-controlled large river is more intensive than that of rivers under natural conditions? (3) Would mid-channel bar building be minimized downstream of the engineering-controlled river confluence because of a long-lasting scouring? Specifically, the study aims to (1) investigate changes of water surface gradient at three gauging in the uppermost Atchafalaya (RK0 to RK69) River during 1935-2016, (2) estimate changes of the thalweg elevation and the average bed elevation from bank to the bank during 1998-2006, and (3) to quantify changes in sediment mass along the channel during 1998-2006. Beyond its scientific purpose, findings gained from this study can have crucial research and practical implications for sediment transport and delivery to the Mississippi River Delta, specifically, and to the other world's sinking river deltas, in general.

\section{Case Study Site}

The 220-km Atchafalaya River is the largest distributary of the Mississippi River (Figure 1), which is the largest river system in North America. The Atchafalaya River receives the entire flow from the Red River and approximately 25\% of the Mississippi River flow, discharging $199 \mathrm{~km}^{3}$ of freshwater into the Northern Gulf of Mexico annually over the past two decades [31]. Due to the large flow volume and sediment load [31,32], channel morphodynamics of the Atchafalaya River is highly complex and strongly affected by human activities in the past. In the 18th century, the three rivers were connected by the Lower Old River (Figure 1), a previous meander of the Mississippi River. Between 1855 and 1880, a large number of log jams were removed in the Red River and the Atchafalaya River, resulting in a steady increase of water from the Red River and Mississippi River into the Atchafalaya River. It was reported that the bankfull discharge of the Atchafalaya River at Simmesport increased from 850 cubic meters per second $\left(\mathrm{m}^{3} \mathrm{~s}^{-1}\right)$ in 1855 to $13,000 \mathrm{~m}^{3} \mathrm{~s}^{-1}$ in 1950 [29].

By the early 1950s, considerable concern was raised over the potential of the Atchafalaya River completely capturing the Mississippi River flow [33]. For preventing the possible avulsion and the future enlargement of the Atchafalaya, the U.S. Army Corps of Engineers (USACE) built a Low Sill Control Structure in 1963 to manage the flow into the Atchafalaya to prevent potential avulsion [30]. After that, $70 \%$ of total discharge in the two rivers at the latitude of Red River Landing (Figure 1) was allocated to the Mississippi and the remaining 30\% was allocated to the Atchafalaya. The Mississippi flood of 1973 seriously destroyed the structure. Therefore, an Auxiliary Control Structure was built in 1986 to reduce the pressure of the Low Sill Structure. The Sidney A. Murray Jr. Hydroelectric Station, completed in 1990, is only operated during low flow. The current system contains two river confluences which are the confluence between the diversion Outflow Channel and the Atchafalaya River and the confluence between the Lower Old River and the Red River (RK0). The Outflow Channel dominates the flow and sediment transport, while the Lower Old River is controlled by a navigation lock and is mainly used for the navigation between the Mississippi River and the Atchafalaya River.

Several studies have investigated morphologic changes in the uppermost Atchafalaya riverbed in the past [29,30,34]. Latimer and Schweizer [29] reported an increased river depth in the first $92 \mathrm{~km}$ of the Atchafalaya River between 1880 and 1950 and estimated a channel bed erosion of 177 million cubic meters between 1932 and 1950. Mossa [30] found that the average thalweg elevation in the first 16-km channel downstream of the Red River/Outflow Channel confluence decreased by 2-3 $\mathrm{m}$ during 1963-2006. By analyzing instantaneous discharge values at Simmesport, Mossa [30] also reported that the Atchafalaya channel geometry (i.e., width and cross-sectional area) continued to change after the construction of the ORCC until the 1990s. These studies showed a degradation trend of the uppermost Atchafalaya riverbed. However, the conclusions from these previous studies were made either without giving detailed method descriptions or only utilizing simply thalweg data and several cross-sectional areas. It is still unclear how recent changes of the whole riverbed from bank to bank in response to the natural and human interventions. 


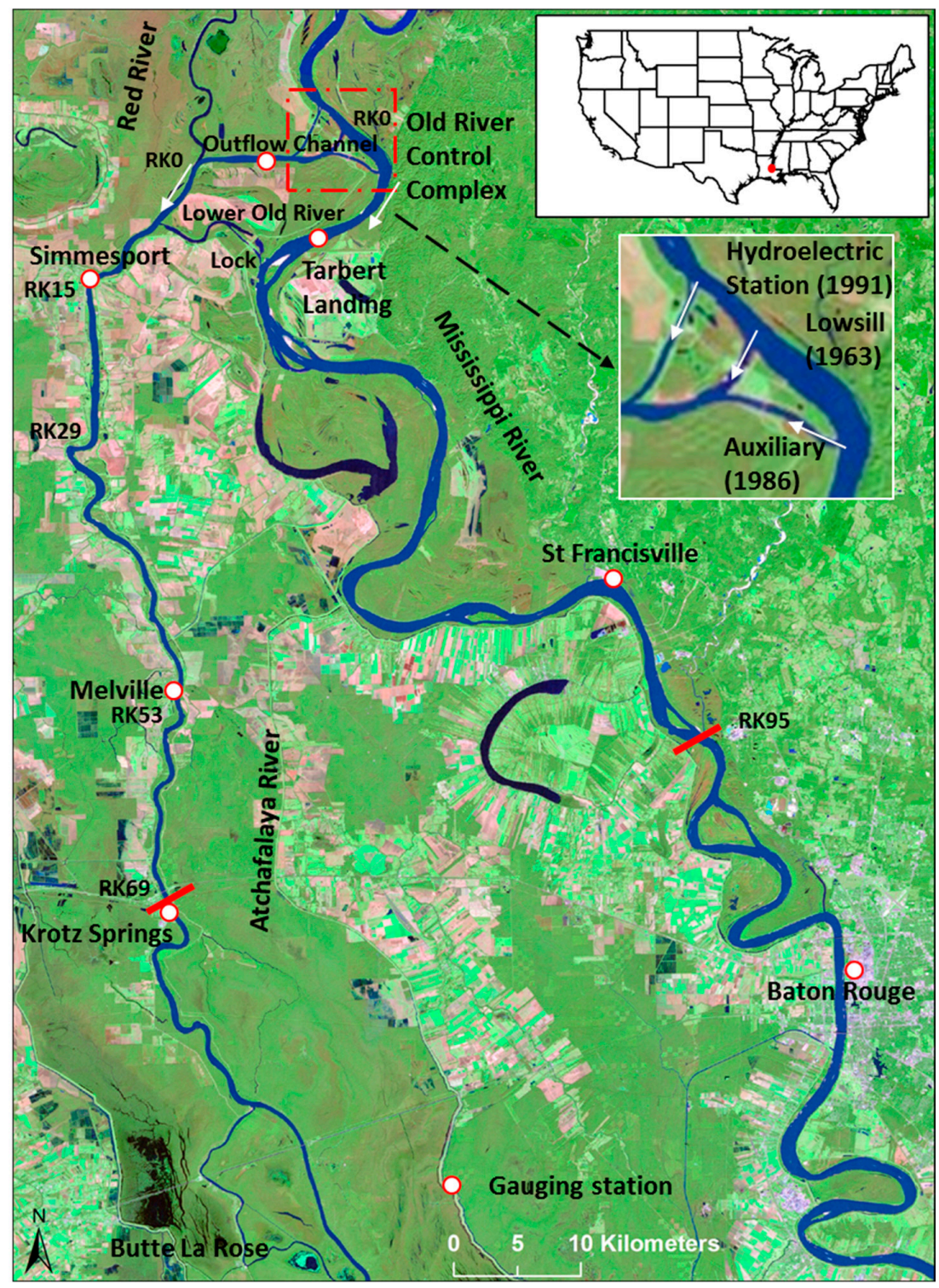

Figure 1. The uppermost Atchafalaya River (left) and the Lowermost Mississippi River (right). The Mississippi-Atchafalaya River diversion (also known as the Old River Control Complex) has three diversion channels, controlling the amount of flow into the Atchafalaya River at an approximately $25-75 \%$ ratio. The Outflow Channel/Red River confluence mainly controls sediment and water discharge, while the Lower Old River is locked and used for navigation. The background image is a Landsat imagery (Band742).

The Atchafalaya River has a single channel in the uppermost 93-km channel, while it has multiple channels downstream. The river is confined by levees on its left bank down to the mouth and on the right bank down to RK 118. In the studied reach, the channel is also protected by revetment. The average width of the uppermost Atchafalaya River is $500 \mathrm{~m}$. The river is a sand-bed river with median grain sizes typically ranging from 0.1 to $1 \mathrm{~mm}$. The suspended sediment concentration and suspended sediment load is about $130 \mathrm{mg} \mathrm{L}^{-1}$ and 33 million tons per year at Melville at RK 53 [35] (Figure 1). The uppermost Atchafalaya River is underlain by substratum sands due to the ancient Mississippi River meander [29]. There are no dredging activities needed in this reach (USACE, Washington, DC, USA, 1974). 


\section{Material and Methods}

\subsection{River Bathymetry and Hydrologic Data}

This study utilized three datasets: single-beam bathymetry survey data, and daily river discharge and stage records. The single-beam bathymetry data covered the entire channel from bank to bank and part of the floodplain conducted by the USACE (https:/www.mvn.usace.army.mil/Missions/ Engineering/Geospatial-Section/) along the Atchafalaya River in 1998 and 2006 (Figure 2). Each dataset contains approximately 210 cross-sections and the distance between every two cross-sections was about 200-400 m. In each cross-section, there were about 20 sounding vertices (elevation measurements) with about 30-m distance between two adjacent points. The survey datasets from the two years are comparable because the locations of all survey points were held consistent during different surveys. Similar datasets were used in studying long-term bed deformation in the Lower Mississippi River and showed great merit in estimating bed deformation [36,37].

Daily river stage and discharge data between 1930 and 2016 were obtained from four gauging stations operated by the USACE in the uppermost Atchafalaya River and the diversion Outflow Channel (Figure 1). These stations are at Simmesport (\#03045), Melville (\#03060), Krotz Springs (\#03075), and Old River Outflow Channel (\#02600).

\subsection{Riverbed Deformation Analysis}

Single-beam measurements in 1998 and 2006 were interpolated to $10 \times 10 \mathrm{~m}$ digital elevation model (DEM) data using the Kriging interpolation method (Figure 2). A recent study by Wu, et al. [38] compared seven different interpolation methods for similar single-beam data in the lowermost Mississippi River. They found that the Kriging method has relatively higher accuracy (i.e., about $2 \mathrm{~m}$ RMSE) in interpolating the sounding points. Each of the two generated DEM datasets were divided into 43 1-mile-long subreaches (Figure 2). The divided DEM data then was input into ArcGIS (ESRI, Redlands, CA, USA) (Figure 3). An add-in software Geomorphic Change Detection in ArcGIS [39,40] was used to calculated riverbed elevation changes of the 2-year DEM on a cell-by-cell basis in each subreach (Figure 3). Net volume change was then estimated by multiplying the calculated elevation change by the surface area of each cell (i.e., $100 \mathrm{~m}^{2}$ ). Deposition and erosion of the riverbed in each of the 43 subreaches were then analyzed. Channel thalweg was defined by finding the lowest elevation point in each cross-section.
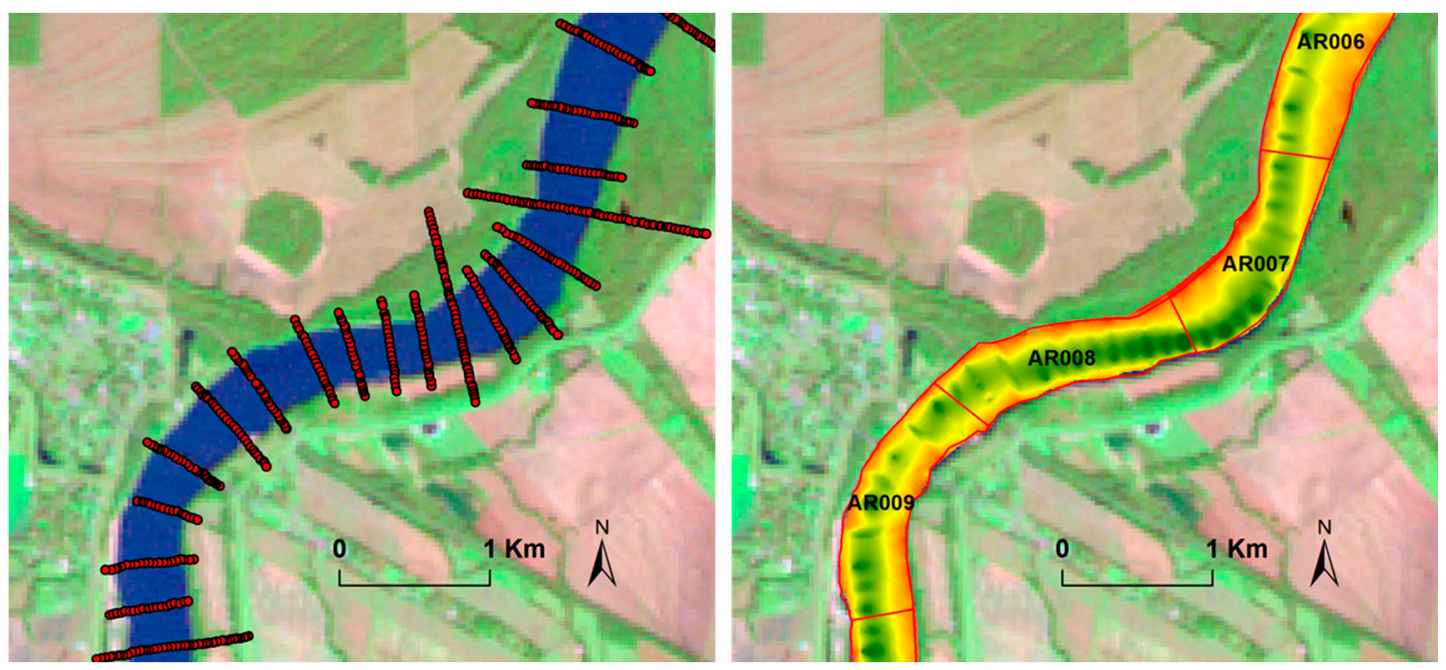

Figure 2. Left: Raw single beam survey data used to develop the riverbed digital elevation model (DEM). Right: DEM data were generated through interpolation for the uppermost 69-km Atchafalaya River. Each subreach represents a 1600-m (1-mile) long reach in bankfull width. 


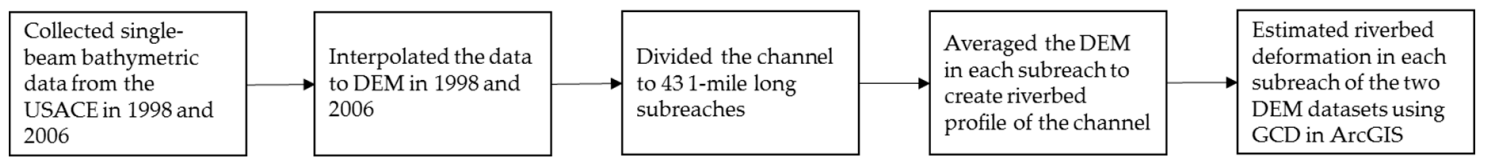

Figure 3. Flowchart of the riverbed deformation analysis.

\subsection{Hydraulic Analysis}

Water surface elevation was obtained by analyzing river stage data at Simmesport (upstream), Melville, and Krotz Springs (downstream) gauging stations along the $69-\mathrm{km}$ uppermost Atchafalaya River (Figure 1). Nine gradient curves of water surface elevation were developed at the decadal-time interval between 1935 and 2016 using specific-discharge analysis. The method holds discharge constant to observe trends in water surface elevation over time. The rating curve in 1962 was also generated to show the water surface elevation right before the operation of the Old River Control Complex in 1963. Long-term changes in the relationship between the discharge and river stage at Simmesport were analyzed to verify the changes in water surface elevation at Simmesport.

Due to a lack of gauging stations in the lowermost Red River, the discharge from the Outflow Channel of the Mississippi-Atchafalaya diversion was subtracted from the discharge at Simmesport to estimate the discharge from the Red River. The discharge ratio between the diversion Outflow Channel and the Red River was then calculated.

To assess channel hydraulic properties and flow conditions, we computed the global Reynolds Number $\left(R_{e}\right)$ (Equation (1)), local Reynolds Number $\left(R_{e}{ }^{\prime}\right)$ (Equation (2)), bed shear stress $(\tau)$ (Equation (3)), global Froude Number $\left(F_{r}\right)$ (Equation (4)), and local Froude Number $\left(F_{r}^{\prime} r\right.$ (Equation (5)) at the three gauging stations under three flow conditions, i.e., low flow, medium flow, and high flow. The flow conditions were divided based on long-term hydrography at Simmesport.

$$
R_{e}=\frac{\bar{v} r}{\vartheta}
$$

where $R_{e}$ is Reynolds number, $\bar{v}$ is the section-averaged velocity $\left(\mathrm{m} \mathrm{s}^{-1}\right), r$ is the hydraulic radius (m), $\vartheta$ is the kinematic viscosity of water.

$$
R_{e}^{\prime}=\frac{\bar{v} d}{\vartheta}
$$

where $d$ is the characteristic diameter of particles of bottom sediments $(0.5 \mathrm{~mm})$.

$$
\tau=\rho g r s
$$

where $\tau$ is bed shear stress $\left(\mathrm{N} \mathrm{m}^{-2}\right), \rho$ is the density of water $\left(\mathrm{kg} \mathrm{m}^{-3}\right), r$ is the hydraulic radius $(\mathrm{m})$, and $s$ is water slope $\left(\mathrm{m} \mathrm{m}^{-1}\right)$. In this study, we used the kinematic viscosity of water at $20^{\circ} \mathrm{C}$ $\left(1.004 \times 10^{-6} \mathrm{~m}^{2} \mathrm{~s}^{-1}\right)$ and the density of water at $20^{\circ} \mathrm{C}\left(998.2 \mathrm{~kg} \mathrm{~m}^{-3}\right)$ to calculate $R_{e}$ and $\tau$.

The global and local Froude number at the three gauging stations were computed as follows:

$$
\begin{gathered}
F_{r}=\frac{\bar{v}}{\sqrt{g h}} \\
F^{\prime}{ }_{r}=\frac{\bar{v}}{\sqrt{g d}}
\end{gathered}
$$

where $h$ is hydraulic mean depth (m) and $d$ is the characteristic diameter of particles of bottom sediments $(0.5 \mathrm{~mm})$. 


\section{Results}

\subsection{Changes in Thalweg and Riverbed Elevation}

Comparing two thalweg profiles in 1998 and 2006, we found that the thalweg elevation had little changes for the reach upstream of RK 28 (Figure 4). However, for the reach downstream of RK 28, the thalweg elevation increased in most of the river channel pools during 1998-2006. For instance, the elevation of the deepest pool at RK 29 was $46 \mathrm{~m}$ below sea level in 1998, but $33 \mathrm{~m}$ below sea level in 2006, showing aggradation of $13 \mathrm{~m}$ in the pool area. As a whole, the average elevation along the whole thalweg increased slightly from -11.7 to $-11.4 \mathrm{~m}$ during $1998-2006$. Interesting also is that there seemed to be a downstream migration of the pool areas in the river reach below RK 29.

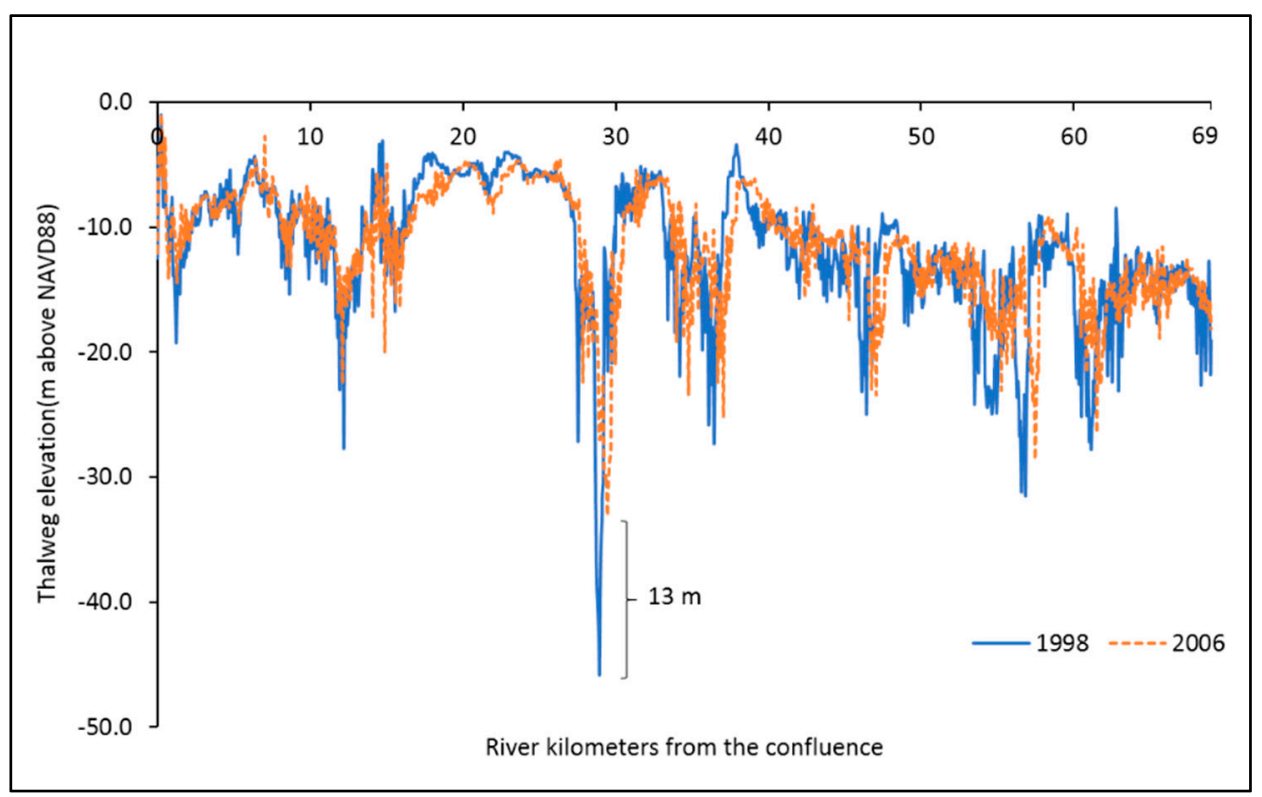

Figure 4. Changes in thalweg profiles from 1998 (blue solid line) to 2006 (orange dash line) in the uppermost $69-\mathrm{km}$ Atchafalaya River. The $x$-axis is the river kilometers from the confluence between the Red River and the Outflow Channel of the Mississippi-Atchafalaya River diversion.

The average bed elevation of the 69-km channel reduced by $1.9 \mathrm{~m}$ from 1998 to 2006 (i.e., from -4.9 to $-6.8 \mathrm{~m}$ ) (Figure 5). Almost the entire channel experienced erosion, especially for the reach between RK 12 and RK 26, where about $3.8 \mathrm{~m}$ of riverbed was eroded on average (Figure 6). The bed slope of the studied reach reduced from $1.4 \times 10^{-4}$ to $1.0 \times 10^{-4}$ during 1998-2006. 


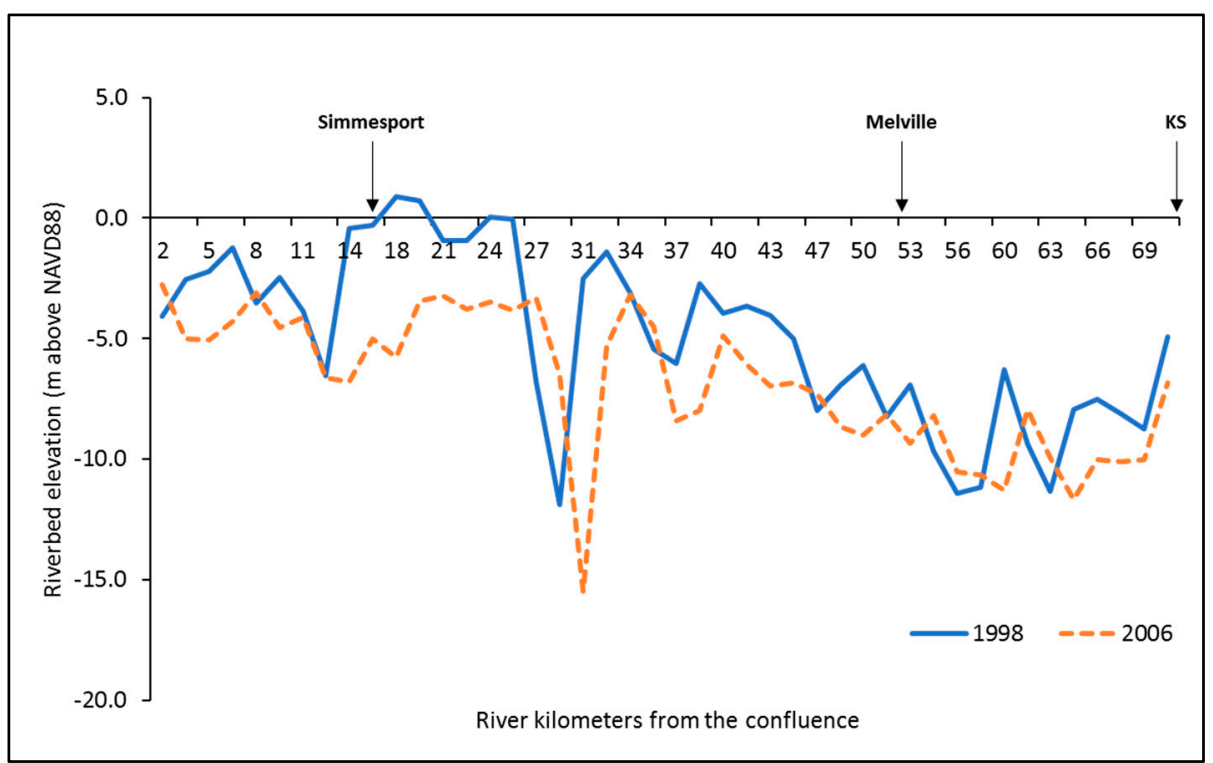

Figure 5. Changes in average bed elevation during 1998-2006 in the uppermost Atchafalaya River. The channel is a $69-\mathrm{km}$ reach downstream of the Outflow Channel (OC) outlet of the Mississippi-Atchafalaya River diversion (RK 0). The $x$-axis is the river kilometers from the confluence on the Red River and the Outflow Channel.

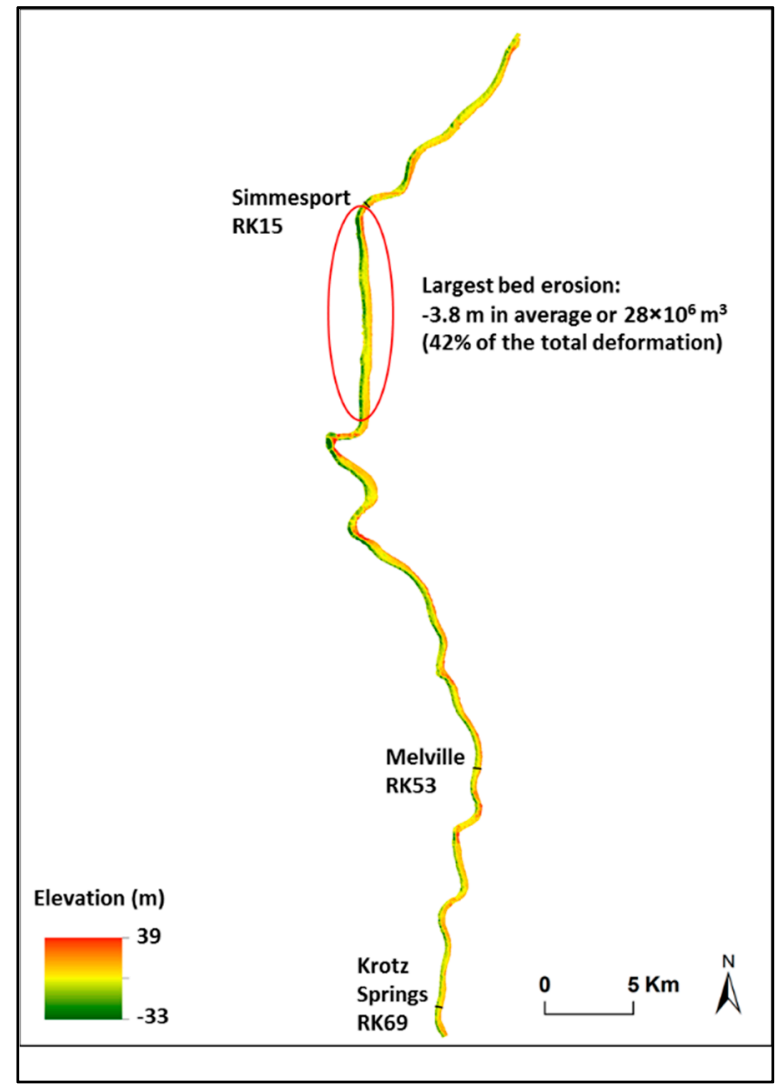

Figure 6. Changes in average bed elevation during 1998-2006 in the uppermost Atchafalaya River. The channel is a $69-\mathrm{km}$ reach downstream of the Outflow Channel (OC) outlet of the Mississippi-Atchafalaya River diversion (RK 0). The $x$-axis is the river kilometers from the confluence on the Red River and the Outflow Channel. 


\subsection{Volume Change of the Riverbed Sediment}

The total sediment eroded from the riverbed was about $6.6 \times 10^{7} \mathrm{~m}^{3}$ during 1998-2006 or $1.1 \times 10^{5} \mathrm{~m}^{3} \mathrm{~km}^{-1}$ year $^{-1}$ (Figure 7). The largest erosion occurred in the reach between RK 14 and RK 31 , where about $2.8 \times 10^{7} \mathrm{~m}^{3}$ sediment was scoured, accounting for $42 \%$ of the total eroded sediment of the entire channel. Aggradation only occurred in two subreaches (i.e., RK 27 and RK 56) and the amount of the deposited sediment was less than $1 \times 10^{6} \mathrm{~m}^{3}$. The total volume of eroded sediment was equivalent to $8.0 \times 10^{7}$ metric tons, assuming 1.2 metric tons per cubic meter bulk density of the riverbed sediment.

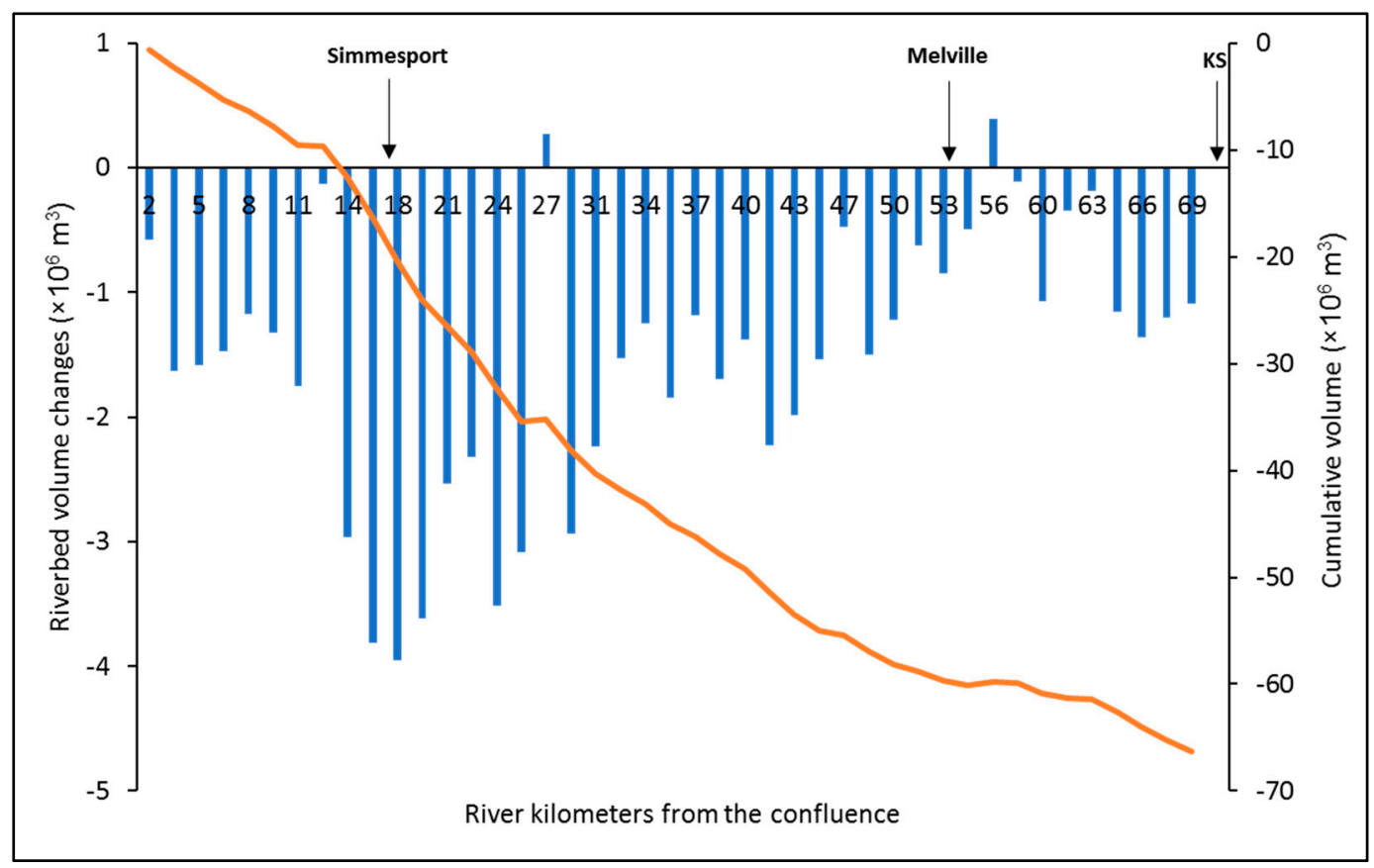

Figure 7. Volume changes of riverbed sediment during 1998-2006 in the uppermost Atchafalaya River. The channel is a 69-km reach downstream of the Outflow Channel (OC) outlet of the Mississippi-Atchafalaya River diversion (RK 0). The orange line is the cumulative sediment volume.

\subsection{Long-Term River Flow and Changes in Water Surface Gradient}

Discharge in the diversion Outflow Channel was usually greater than that in the Red River, although the pattern reversed occasionally when floods occurred in the Red River (Figure 8). The average daily discharge during 1963-2016 in the Outflow Channel and the Red River were 4052 and $1796 \mathrm{~m}^{3} \mathrm{~s}^{-1}$, respectively. The annual discharge ratio between the Outflow Channel and the Red River varied largely from 0.64 to 7.7 with an average ratio of 2.47. Flood frequency increased during the past 90 years (Figure 8).

Over the 81 years from 1935 to 2016, the river stage at a specific discharge of $8000 \mathrm{~m}^{3} \mathrm{~s}^{-1}$ $\left( \pm 100 \mathrm{~m}^{3} \mathrm{~s}^{-1}\right)$ decreased by $5.8,5.6$, and $4.9 \mathrm{~m}$ at Simmesport, Melville, and Krotz Springs, respectively (Figure 9 and Table 1). Before 1986, the river stage kept decreasing during each decade and the decreased stage was 6.1,5.5, and $5.0 \mathrm{~m}$ at the three stations, respectively. However, the changes became inconsistent at the three locations after 1986. For example, during 1986-1996, the stage increased $0.6 \mathrm{~m}$ at Simmesport and had little changes at Melville and Krotz Springs (i.e., 0.09 and $0.04 \mathrm{~m}$ ). During 1996-2006, the stage reduced by 0.2, 0.3, and $0.2 \mathrm{~m}$ at Simmesport, Melville, Krotz Springs, respectively. During 2006-2016, the stage increased at Melville and Krotz Springs (i.e., 0.2 and $0.3 \mathrm{~m}$ ) while it had little change at Simmesport $(-0.08 \mathrm{~m})$. Overall, the stage increased 0.4 at Simmesport and had no significant changes at Melville and Krotz Springs (i.e., -0.04 and $0.09 \mathrm{~m}$ ) during 1986-2016. 


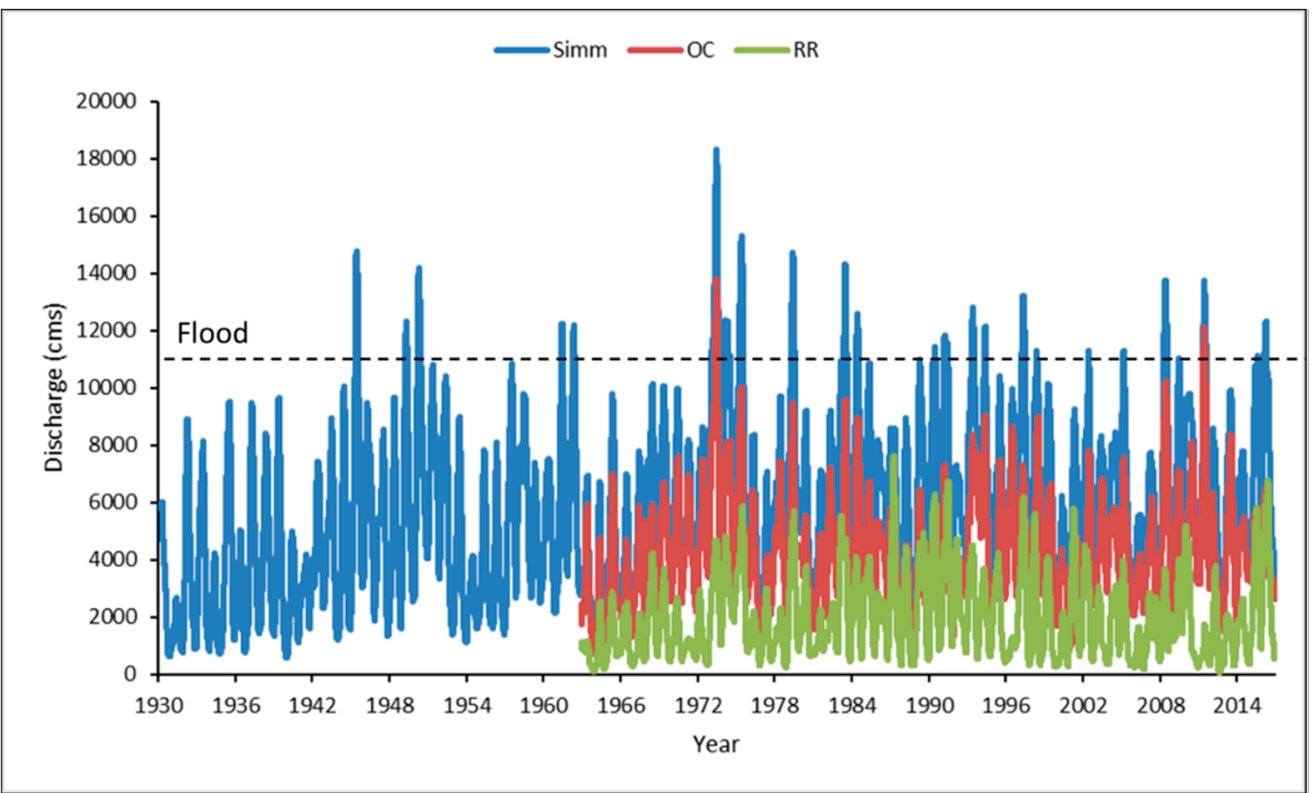

Figure 8. Daily discharge (in cubic meters per second, $\mathrm{m}^{3} \mathrm{~s}^{-1}$ ) at Simmesport (Simm, blue line), the Outflow Channel of the Mississippi-Atchafalaya River diversion (OC, redline), and the Red River (RR, green line) between 1930 and 2016. The black dashed line is the moderate flood discharge at Simmesport.

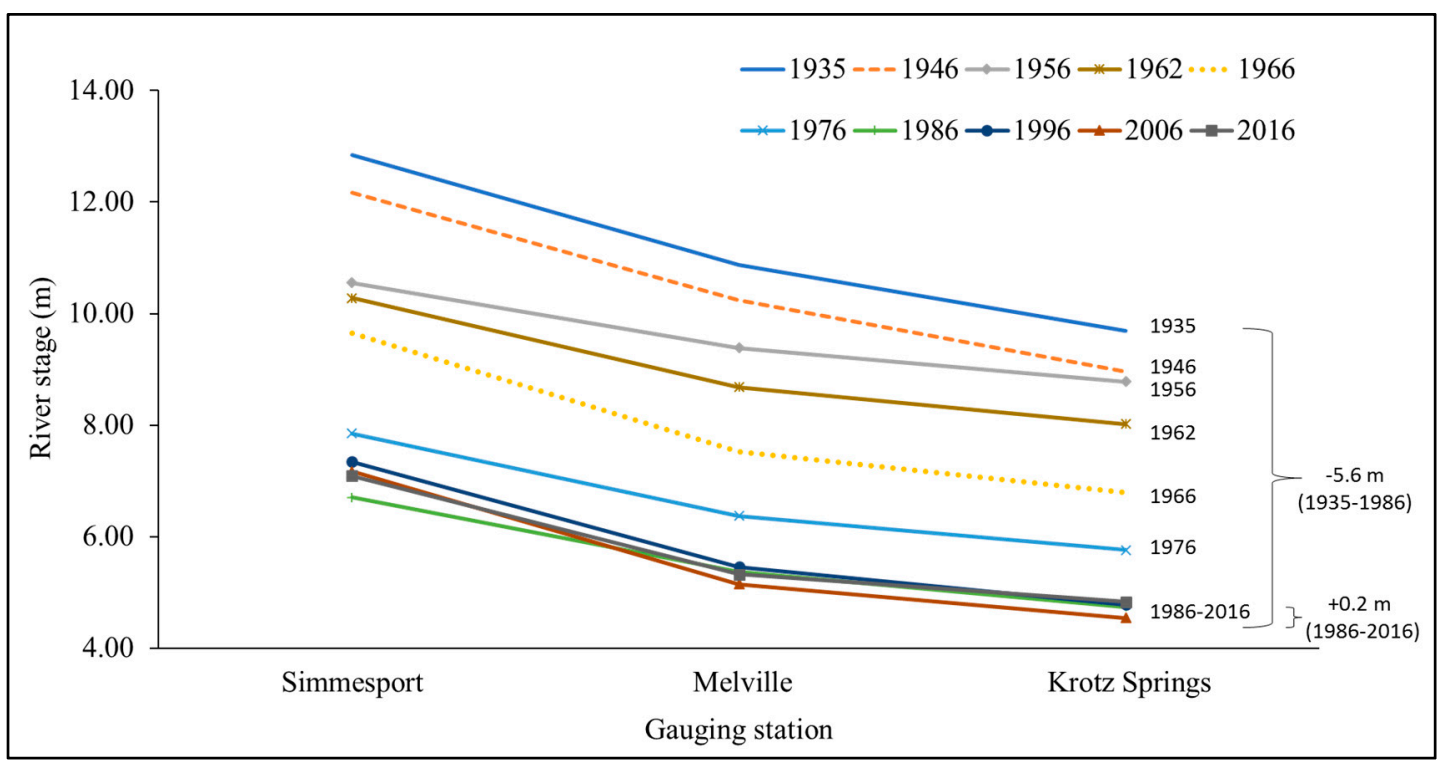

Figure 9. River stages at Simmesport, Melville, and Krotz Springs along the uppermost Atchafalaya River during high flows (i.e., $8000 \pm 100 \mathrm{~m}^{3} \mathrm{~s}^{-1}$ ) between 1935 and 2016. 
Table 1. River stage changes at Simmesport, Melville, and Krotz Springs (KS) along the uppermost Atchafalaya River during 1935-2016 at discharge $8000 \pm 100 \mathrm{~m}^{3} \mathrm{~s}^{-1}$.

\begin{tabular}{ccccc}
\hline Period & Simmesport $(\mathbf{m})$ & Melville $(\mathbf{m})$ & KS $(\mathbf{m})$ & Average $(\mathbf{m})$ \\
\hline $1935-1946$ & -0.7 & -0.6 & -0.7 & -0.7 \\
$1946-1956$ & -1.6 & -0.9 & -0.2 & -0.9 \\
$1956-1966$ & -0.9 & -1.9 & -2.0 & -1.6 \\
$1966-1976$ & -1.8 & -1.2 & -1.0 & -1.3 \\
$1976-1986$ & -1.1 & -1.0 & -1.0 & -1.1 \\
$1986-1996$ & 0.6 & 0.1 & 0.0 & 0.3 \\
$1996-2006$ & -0.2 & -0.3 & -0.2 & -0.2 \\
$2006-2016$ & -0.1 & 0.2 & 0.3 & 0.1 \\
Total & -5.8 & -5.6 & -4.9 & -5.4 \\
\hline
\end{tabular}

At Simmesport gauging station, based on the analysis of discharge-stage rating curves, the river stage lowered about $6.0 \mathrm{~m}$ from 1935 to 2016 for the given discharge (i.e., $8000 \mathrm{~m}^{3} \mathrm{~s}^{-1}$.) (Figure 10). The only exception is the period of 1986-1996 when the stage increased $0.45 \mathrm{~m}$ at the same discharge. The largest stage decrease occurred between 1966 and 1976 (i.e., $-2.1 \mathrm{~m}$ ). The average stage change during every decade before 1996 was $-0.97 \mathrm{~m}$. The stage changes after 1996 were much slower and averaged $-0.1 \mathrm{~m}$ (Table 2). Overall, the stage changes based on the discharge-stage rating curves at Simmesport have the same trend as single day stage changes showing in Figure 9.

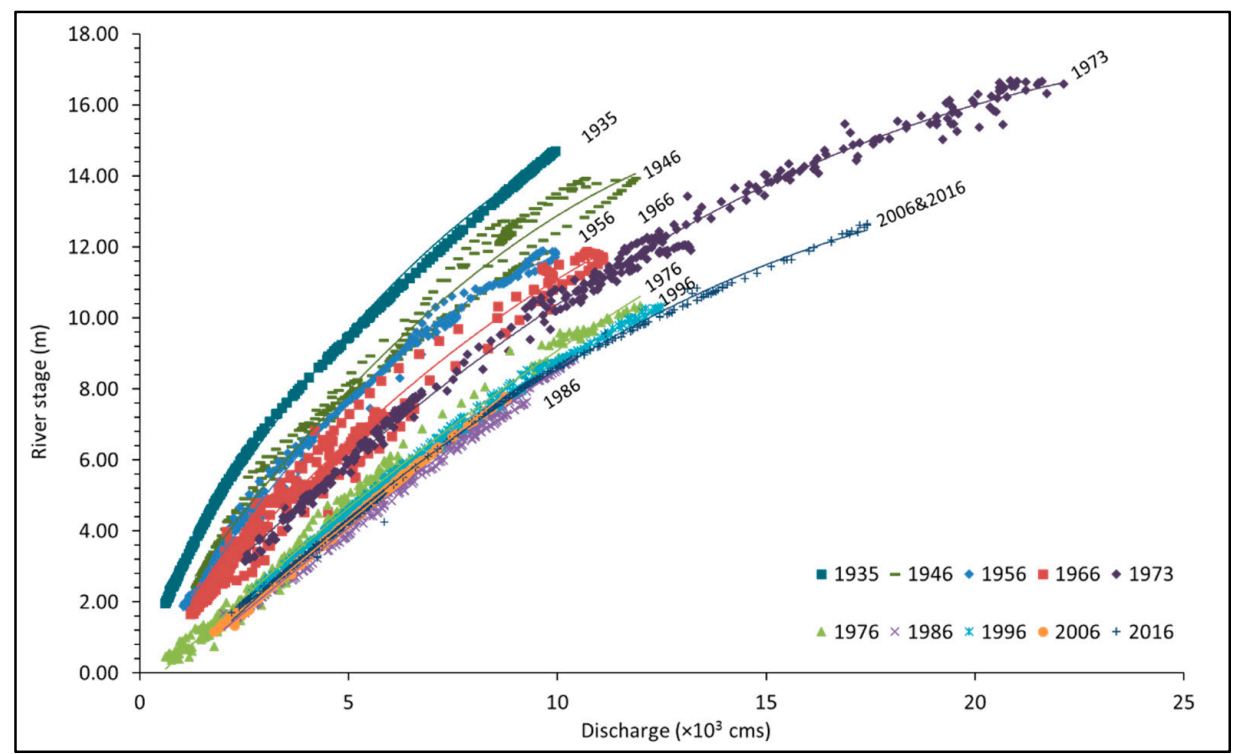

Figure 10. Changes in the relationship between daily mean river stage and discharge at Simmesport (i.e., $8000 \mathrm{~m}^{3} \mathrm{~s}^{-1}$ ) between 1935 and 2016.

Table 2. Decadal rive stage changes under a specific discharge of $8000 \mathrm{~m}^{3} \mathrm{~s}^{-1}$ at Simmesport between 1935 and 2016 (Figure 8).

\begin{tabular}{|c|c|c|}
\hline Period & River Stage Change (m) & Stage Change Rate (m year ${ }^{-1}$ \\
\hline $1935-1946$ & -1.8 & -0.15 \\
\hline 1946-1956 & -0.6 & -0.05 \\
\hline 1956-1966 & -1.1 & -0.10 \\
\hline 1966-1976 & -2.1 & -0.19 \\
\hline 1976-1986 & -0.6 & -0.05 \\
\hline 1986-1996 & 0.4 & 0.04 \\
\hline 1996-2006 & -0.1 & -0.01 \\
\hline 2006-2016 & -0.1 & -0.01 \\
\hline
\end{tabular}




\subsection{Reynolds Number, Bed Shear Stress, and Froude Number}

The calculated global Reynolds numbers $(R e)$ for the uppermost Atchafalaya varied between $6.8 \times 10^{6}$ and $1.78 \times 10^{7}$ at three stations under low, medium, and high flow conditions. Three ranges of $R e$ are usually defined, laminar, transitional, and turbulent flow, based on the $R e$ of, respectively, $<500,500-2000$, and $>2000$. The results show that the flow in the uppermost $69-\mathrm{km}$ Atchafalaya River is turbulent. The calculated bed shear stress ranged from 2.6 to $9.8 \mathrm{~N} \mathrm{~m}^{-2}$. These values are also much greater than the critical bed shear stress in a sand-bed river with a median grain size between 0.1 and $1 \mathrm{~mm}$ (i.e., 0.1-0.47 $\mathrm{N} \mathrm{m}^{-2}$ ) [41]. The global Froude numbers were all less than 1, but the local Froude numbers were much greater than 1, showing that the flow of the uppermost Atchafalaya is supercritical.

\section{Discussion}

\subsection{Indication of the Continuous Decline of Water Surface Gradient in the Past 80 Years}

The changes in water surface gradient indicate that considerable riverbed degradation has occurred in the uppermost Atchafalaya River at least since the 1930s (Figures 9 and 10). Considering the reported bed degradation [31] for some cross-sections of the river reach between 1880 and 1950, the uppermost Atchafalaya River channel continued degrading in the past 150 years. As mentioned before, the scour downstream of river confluence could deepen with increased discharge ratio between the tributary and main channels [3-5]. Before the log removal occurred during 1855-1880, the Red River can be seen as the main channel and the Mississippi River was a tributary with little contribution to the Atchafalaya River. Therefore, the discharge ratio between the tributary and the main channel was near zero (Figure 11). The bankfull discharge in the Atchafalaya River gradually increased from 850 to $13,000 \mathrm{~m}^{3} \mathrm{~s}^{-1}$ from 1855 to 1950 (Latimer and Schweizer, 1951, [29]). This indicates that the discharge ratio gradually increased during 1855-1950 (Figure 12). Although the Old River Control Complex was constructed in 1963, the flow increase from the diversion Outflow Channel was not fully controlled until 1976 (Figure 12). This indicates that the discharge ratio between the tributary and the main channel have increased from 1855 to 1976. The ratio was 2.47 during 1963-2016. Therefore, we can conclude that the effects of discharge ratio variation on downstream bed morphology could last very long.

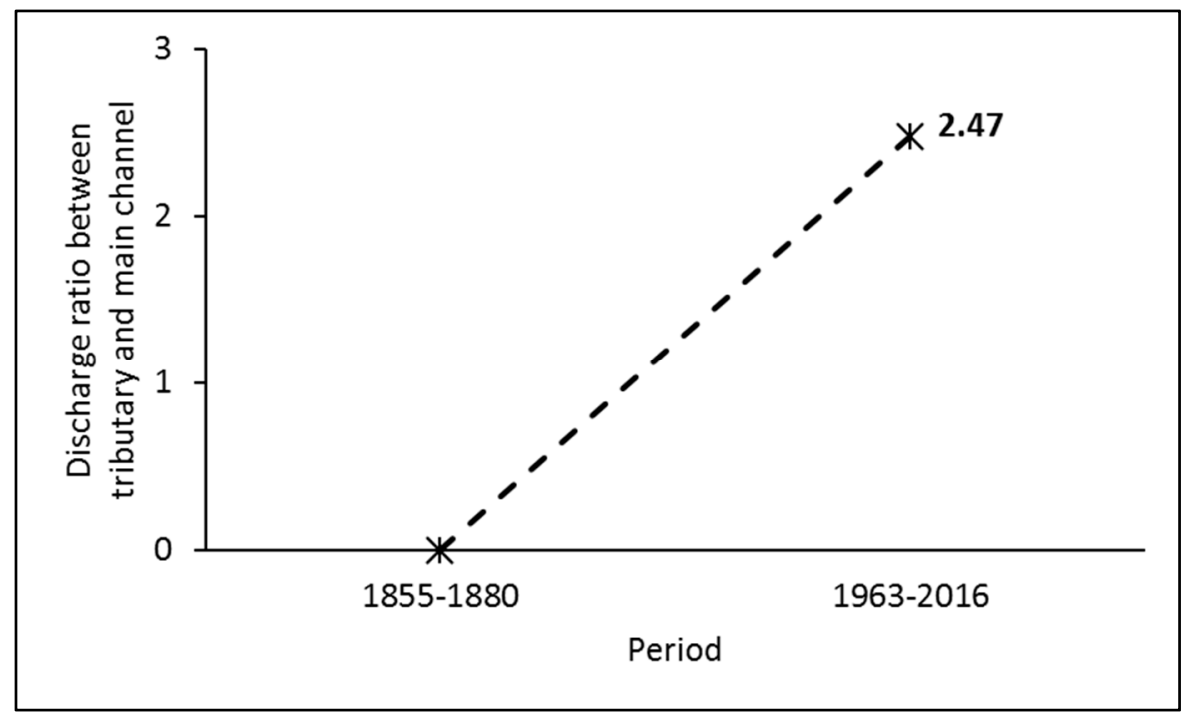

Figure 11. Discharge ratio between diversion Outflow Channel (tributary) and the Red River (main channel) of the Outflow Channel/Red River confluence during the period of 1855-2016. The increase was very likely linear because the discharge ratio increased linearly after 1930 showing in Figure 12. 


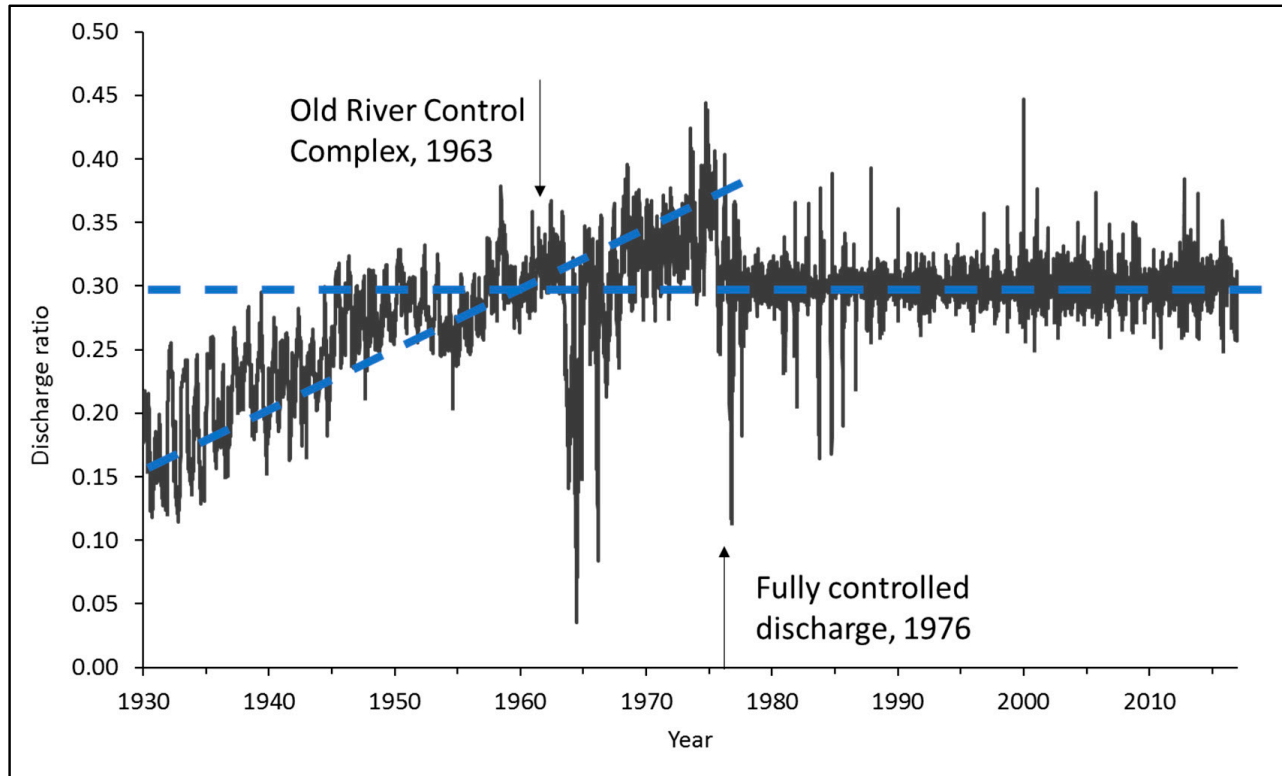

Figure 12. Discharge ratio of the Atchafalaya River at Simmesport to the latitude flow (total discharge of the Mississippi River mainstem at Tarbert Landing and the Atchafalaya River discharge).

Even when the diverted flow was started to be controlled after the operation of the Low Sill Structure in 1963, the channel continued to be scoured. For instance, from 1962 to 1966, the river stage at specific discharge lowered 0.27, 0.70, and $0.76 \mathrm{~m}$ at Simmesport, Melville, and Krotz Springs gauging stations, respectively. This phenomenon was also revealed from the thalweg study by Mossa [33]. It can be well explained by the continuing increased discharge ratio between the two tributaries since the confluence angle was fixed after 1963 (Figure 12). The hydraulic analysis also shows that the upmost 69-km Atchafalaya River has a much larger Reynolds number, shear stress, and local Froude number (Table 3). The flow in the river reach is turbulent and supercritical under low, medium and high flow conditions. As a result, sediment deposition is impossible, and the riverbed was severely scoured. The mid-channel bars are also impossible to form under such large bed shear stress and drag force of the flow. The decrease in the stage continued until 1986 but it was still found during 1996-2006. However, the minor changes of the stage at the three gauging stations between 1986 and 2016 shows that the channel has been close to equilibrium after five decades of river regulation.

Table 3. Global and local Reynolds Number $\left(R e, R e^{\prime}\right)$, bed shear stress, and global and local Froude Number $\left(F r, F r^{\prime}\right)$ under different flow conditions at Simmesport (RK 15), Melville (RK 29), and Krotz Springs (RK 53). Three flow conditions, i.e., high (H), medium (M), and low (L) flow, were derived based on the long-term discharge records at Simmesport.

\begin{tabular}{|c|c|c|c|c|c|c|c|c|}
\hline Location & Flow & $\begin{array}{c}\text { Discharge } \\
\left(\mathrm{m}^{3} \mathrm{~s}^{-1}\right)\end{array}$ & $\begin{array}{l}\text { Velocity } \\
\left(\mathrm{m} \mathrm{s}^{-1}\right)\end{array}$ & $\begin{array}{c}\operatorname{Re} \\
\left(\times 10^{6}\right)\end{array}$ & $\begin{array}{c}R e^{\prime} \\
\left(\times 10^{6}\right)\end{array}$ & $\begin{array}{l}\text { Shear Stress } \\
\qquad\left(\mathrm{N} \mathrm{m}^{-2}\right)\end{array}$ & $F r$ & $F r^{\prime}$ \\
\hline \multirow[t]{3}{*}{ Simmesport } & $\mathrm{H}$ & 8014 & 1.3 & 16.1 & 627 & 8.5 & 0.11 & 17.96 \\
\hline & M & 5550 & 1 & 11.7 & 517 & 4.7 & 0.10 & 14.83 \\
\hline & $\mathrm{L}$ & 3058 & 0.7 & 6.8 & 366 & 2.6 & 0.08 & 10.50 \\
\hline \multirow[t]{3}{*}{ Melville } & $\mathrm{H}$ & 8014 & 1.3 & 16.3 & 634 & 8.5 & 0.11 & 18.17 \\
\hline & M & 5550 & 1.1 & 11.8 & 549 & 4.5 & 0.10 & 15.73 \\
\hline & $\mathrm{L}$ & 3058 & 0.7 & 6.9 & 350 & 2.7 & 0.07 & 10.04 \\
\hline \multirow[t]{3}{*}{ Krotz Springs } & $\mathrm{H}$ & 8014 & 1.2 & 17.8 & 604 & 9.8 & 0.10 & 17.32 \\
\hline & M & 5550 & 0.9 & 13 & 457 & 5.9 & 0.08 & 13.11 \\
\hline & $\mathrm{L}$ & 3058 & 0.6 & 7.4 & 296 & 3.5 & 0.05 & 8.48 \\
\hline
\end{tabular}

At Simmesport, the largest bed erosion occurred during 1966-1976 (i.e., $-0.19 \mathrm{~m} \mathrm{year}^{-1}$ ). The two largest floods after 1930 (i.e., the 1973 and 1975 floods, Figure 8) that occurred during this period 
could be a major reason for the largest erosion at Simmesport. During the large floods, it has been found that the suspended sediment concentration (SSC) and suspended sediment load (SSL) was low in the Mississippi River [35,42]. As two-thirds of the Atchafalaya River flow is from the Mississippi River, this type of SSC pattern in the Mississippi River could result in the low SSC and SSL in the Atchafalaya River during floods. Under such conditions, excess stream power would inevitably scour the bed of sand-bed rivers [22,43]. The second-largest bed erosion occurred during 1935-1946 (i.e., $-0.15 \mathrm{~m} \mathrm{year}^{-1}$ ). During this period, except the third-largest flood that occurred in 1945, the local cutoff shortened the distance between the Mississippi River and the Lower Old River which largely increased bed slope and flow into the Atchafalaya River [34]. It was estimated that the increased slope between the Old River and the uppermost Atchafalaya River may have been doubled during low flow [31].

Different from the river stage changes at Simmesport, the largest stage decrease at Melville and Krotz Springs occurred during 1956-1966, instead of 1966-1976. This may indicate that the large floods (especially the 1973 flood) may have less significant effects on the reach further downstream of the confluence. Another possible reason is that the operation of the Old River Control Complex in 1963 scoured the Outflow Channel bed and carried a large amount of sediment to the reach downstream of the confluence. This may have increased local bed slope right below the confluence and therefore, caused higher bed material load transport and corresponding bed erosion at Melville and Krotz Springs during 1956-1966. We consider this is very likely because that riverbed in the Outflow Channel was still scoured over $1 \mathrm{~m}$ during 1992-2013 [36].

The only bed aggradation in the uppermost Atchafalaya River occurred between 1986 and 1996. During this period, two new diversion channels were built downstream of the Auxiliary Structure (1986) and the hydropower station (1991) (Figure 1). The operation of the two new structures may have severely scoured the bed of the new diversion channels and brought a large amount of eroded sediment from the channels to the uppermost Atchafalaya River causing bed aggradation during 1986-1996.

\subsection{Riverbed Erosion during 1998-2006}

We found significant bed erosion during 1998-2006 in the uppermost Atchafalaya River (Figure 5). This is consistent with our stage analysis during the same period (Figure 9). The degradation could be explained in three aspects. First, the channel was still in adjustment to the increased discharge of the tributary channel starting from the 18th century. Second, bed degradation indicates that the input sediment to the channel is less than the sediment transport capacity of the flow. In a sediment transport study for the Atchafalaya, $\mathrm{Xu}$ [30] reported a declining trend of suspended sediment concentration (SSC, i.e., suspended particles smaller than $2 \mathrm{~mm}$ ) at Simmesport from 1975 through 2005. The sediment data were collected two to three times per month by the USGS using a depth-integrated sampler (mostly US D-99) from a survey boat. Based on the sediment records from the USGS, we found that SSC during 1998-2006 (247 mg L ${ }^{-1}$ ) was 24\% lower than that during 1977-1997 (324 mg L-1). A recent study [35] found the similar trend downstream at Melville: SSC and suspended sediment load (SSL) largely reduced from $249 \mathrm{mg} \mathrm{L}^{-1}$ (58 million tons year ${ }^{-1}$ ) in 1980 to $133 \mathrm{mg} \mathrm{L}^{-1}$ (33 million tons year ${ }^{-1}$ ) from 1980 to 2015 at Melville, respectively, i.e., a nearly 80\% reduction. With little changed river discharge, nearly half of the decrease in SSC and SSL delivering into the uppermost Atchafalaya River could be an important reason for channel degradation because of the expending of excess stream power [22]. In another study, Wang and Xu [44] found that compared to $24 \%$ of the diverted water from the Mississippi to the Atchafalaya River, there was only $17 \%$ of bed material load (i.e., sediment comprising the bed that travels either as bedload or suspended load) delivered into the Atchafalaya River. Disproportional bed material load transport may have also caused bed degradation in the uppermost Atchafalaya River. However, the declines in SSC and SSL after 2005 were more gradual than before and the riverbed slope of the channel decreased from 1998 to 2006. These may have reduced bed material load transport during high flow and weakened bed scouring in the recent decade. This is 
also consistent with the almost unchanged river stage at Simmesport, Melville, and Krotz Springs during 2006-2016.

It is interesting to note that although significant bed erosion occurred along the uppermost Atchafalaya River (Figure 5), the thalweg elevation slightly elevated from 1998 to 2006 at many locations, especially at some deepest pools (Figure 4). This indicates (1) elevation changes in thalweg of a river may not always reflect the real varying trend of the bed deformation, and (2) thalweg of pools may migrate along the river. Therefore, care needs to be taken to evaluate morphologic changes of the riverbed only based on the thalweg.

\subsection{Implications}

The Mississippi River Delta (MRD) is losing land at one of the highest rates in the world. It has lost approximately $5000 \mathrm{~km}^{2}$ since 1932 [45]. The only land gain along the Mississippi deltaic plain is on the Atchafalaya-Wax Lake Deltas (AWD). The AWD initially emerged in the Atchafalaya Bay after the 1973 Mississippi River flood [46]. Several factors have been found influencing the deltaic growth, including the frequency of floods [46,47], tropical storms [47-49], cold frontal passage [50], and vegetation colonization $[47,51,52]$. However, as a critical driver for the deltaic growth, the process of sediment transport in the Atchafalaya River was not well studied. Xu [30] quantified the inflow and outflow of the suspended sediment in the Atchafalaya River between 1975 and 2004. Results showed that on average 6 million tons sediment (or 9\% inflow sediment) was retained in the Atchafalaya River Basin. Rosen and $\mathrm{Xu}$ [47] reported suspended sediment yield to the AWD decreased from an average annual of 56 million tons during 1989-1995 to an average annual of 41 million tons during 2004-2010. Both studies focused on the suspended sediment and tried to build the connection between the suspended sediment load and the growth rate of the AWD. However, as a sand-rich delta (nearly $70 \%$ sand) [53], the development of the AWD should be more reliant on coarse sediment instead of the suspended sediment. As previous studies already reported the degradation in the uppermost Atchafalaya riverbed $[31,33]$, it is important to investigate how much sediment was scoured from the bed.

Rouse, Roberts, and Cunningham [46] reported that there was a high rate of deltaic growth of the Atchafalaya and Wax Lake Deltas following the 1973 and 1975 floods. Rosen and Xu [47] also found that floods have been a major contributing factor to the growth of the AWD by comparing 5-year period satellite images over the period from 1989 to 2010. As the AWD are sand-rich deltas, riverine sand sediments have a much greater impact on delta development. The present study clearly shows that the largest bed erosion occurred between 1966 and 1976 in the uppermost Atchafalaya River when large floods occurred. Therefore, it is very likely that the eroded coarse sand from the channel bed may have greatly contributed to the growth of the AWD.

The analysis of the hydrologic survey data revealed about 80 million tons of sediment removal during 1998-2006 in the uppermost Atchafalaya riverbed, which is equivalent to 10 million tons per year $\left(\mathrm{MT}_{\text {year }}{ }^{-1}\right.$ ) erosion rate. This number is in the same order as the previous estimation on bed erosion rate in the uppermost 92-km Atchafalaya River between 1932 and 1950 (i.e., 12 MT year $^{-1}$ ) by Latimer and Schweizer [31]. On the other hand, the specific stage analysis shows that the average stage decreased by $0.2 \mathrm{~m}$ at the three stations during 1996-2006 (i.e., $0.02 \mathrm{~m}_{\text {year }}{ }^{-1}$ ). Based on these estimations, if we assume that the $0.02 \mathrm{~m} \mathrm{year}^{-1}$ stage decrease rate is equivalent to $10 \mathrm{MT}$ year ${ }^{-1}$ sediment erosion rate, the $5.4 \mathrm{~m}$ average decreased stage during 1935-2016 at the three gauging stations is equivalent to an erosion rate of about $2700 \mathrm{MT}$ sediment (or about $33 \mathrm{MT}$ year $^{-1}$ ). Such amount of coarse sediment may have helped fill in the lower Atchafalaya River channels as well as helped the AWD growth in the Atchafalaya Bay. However, the possible relationship between the riverbed erosion and the deltaic growth is neglected in the previous understanding of deltaic development. Additionally, as the riverbed of the uppermost Atchafalaya River reaches equilibrium, the growth rate of the AWD may largely decrease in the future. A detailed relationship between bed deformation and the deltaic growth needs to be elucidated by future studies. The coarse sediment budget of the whole 
Atchafalaya River is also required for understanding long-term availability and transport capacity of sediment, which is crucial for sediment diversion and dredging activities.

Different from the uppermost Atchafalaya River, the Mississippi River channel downstream of the Old River Control Complex tends to deposit sediment due to backwater effects [54-56]. Even in recent decades, about 74 MT sediment was found deposited in the first 95- $\mathrm{km}$ channel downstream of the ORCC during 1992-2013 [36]. With relatively stable and deep channel in the uppermost Atchafalaya River, the water surface gradient between the Mississippi River and the Atchafalaya River could continuously increase, which can increase the risk of a Mississippi River avulsion if a historic flood occurs in the future.

Currently, there are a number of software products for modeling channel processes, in particular: Delft3D-Flow [57], Adaptive Hydraulics (AdH) [58], and RiverFlow2D-Dimensional River Dynamics Model (Hydronia LLC, Florida, USA). In this regard, the work would have acquired a completely different significance if the modeling of this channel system and its comparison with the observed dynamics had been carried out.

\section{Conclusions}

This study investigated river hydraulic changes from 1935 to 2016 and riverbed changes from 1998 to 2006 in the channel of one of the world's largest man-controlled river confluence, the Mississippi-Red-Atchafalaya River confluence. We found that over the past 80 years, flow increase from the Mississippi to the Atchafalaya has resulted in significant bed degradation of the uppermost 69-km Atchafalaya River. Even after the diverted flow from the Mississippi River was controlled in 1963, the uppermost Atchafalaya River channel continued to be scoured. Between 1935 and 1986, the average water surface elevation along the uppermost Atchafalaya reduced by $5.6 \mathrm{~m}$, but the riverbed of this channel seemed to have reached an equilibrium state after 1986. The largest bed erosion occurred during the period with the largest floods showing potential positive effects of floods on the bed erosion. During the period of 1998-2006, a total of about 80 million tons of sediment were eroded in the channel based on the estimation of bathymetric survey data. It is likely that a substantially large amount of coarse sediment (i.e., at least 2700 million tons) was scoured from the channel and moved downstream to the Lower Atchafalaya River during 1935-2016. This large amount of eroded coarse sediment may have greatly contributed to the development of deltaic land in the Atchafalaya Bay over the past 80 years. The findings demonstrate the long-term impacts of river engineering on hydro-morphologic changes of riverbed downstream of large alluvial river confluences. Future studies need to focus on interpreting the detailed relationship between bed deformation and deltaic growth.

Author Contributions: Y.J.X. conceived and designed the study; B.W. and W.X. performed data collection and analysis; B.W. and Y.J.X. wrote the first draft of the manuscript. W.X., H.C., Z.C., and W.Z. contributed to manuscript review and revisions. All authors have read and agreed to the published version of the manuscript.

Funding: This study was mainly supported through a grant from the U.S. National Science Foundation [award 1212112]. The research also benefited from a U.S. Department of Agriculture Hatch Fund project [LAB94459]. During the preparation of this manuscript, Wei $\mathrm{Xu}$ was supported by an award from the China Scholarship Council [CSC NO. 201806140089]; Zhongyuan Chen and Weiguo Zhang received funding support by the Ministry of Science and Technology of the People's Republic of China [Grant \# 2017YFE0107400].

Acknowledgments: The authors thank the U.S. Geological Survey and the U.S. Army Corps of Engineers for making the river stage, discharge, hydrologic survey data, and sediment data available for this study. We are grateful to four anonymous reviewers for their careful reading of this paper and their insightful comments and suggestions, which have helped us clarify and improve the manuscript.

Conflicts of Interest: The authors declare no conflict of interest.

\section{References}

1. Mosley, M.P. An experimental study of channel confluences. J. Geol. 1976, 84, 535-562. [CrossRef]

2. Richards, K.S. A note on changes in channel geometry at tributary junctions. Water Resour. Res. 1980, 16, 241-244. [CrossRef] 
3. Ashmore, P.; Parker, G. Confluence scour in coarse braided streams. Water Resour. Res. 1983, 19, $392-402$. [CrossRef]

4. Best, J.L. Flow dynamics at river channel confluences; implications for sediment transport and bed morphology. Spec. Publ. Soc. Econ. Paleontol. Mineral. 1987, 39, 27-35.

5. Best, J.L.; Reid, I. Separation zone at open-channel junctions. J. Hydraul. Eng. 1984, 110, 1588-1594. [CrossRef]

6. Best, J.L. The morphology of river channel confluences. Prog. Phys. Geogr. 1986, 10, 157-174. [CrossRef]

7. Biron, P.; Roy, A.G.; Best, J.L.; Boyer, C.J. Bed morphology and sedimentology at the confluence of unequal depth channels. Geomorphology 1993, 8, 115-129. [CrossRef]

8. Rhoads, B.L.; Kenworthy, S.T. Flow structure at an asymmetrical stream confluence. Geomorphology 1995, 11, 273-293. [CrossRef]

9. Biron, P.; Best, J.L.; Roy, A.G. Effects of bed discordance on flow dynamics at open channel confluences. J. Hydraul. Eng. ASCE 1996, 122, 676-682. [CrossRef]

10. Lane, S.N.; Biron, P.M.; Bradbrook, K.F.; Butler, J.B.; Chandler, J.H.; Crowell, M.D.; McLelland, S.J.; Richards, K.S.; Roy, A.G. Three-dimensional measurement of river channel flow processes using acoustic doppler velocimetry. Earth Surf. Process. Landf. 1998, 23, 1247-1267. [CrossRef]

11. Biron, P.M.; Ramamurthy, A.S.; Han, S. Three-dimensional numerical modeling of mixing at river confluences. J. Hydraul. Eng. ASCE 2004, 130, 243-253. [CrossRef]

12. Martín-Vide, J.P.; Plana-Casado, A.; Sambola, A.; Capapé, S. Bedload transport in a river confluence. Geomorphology 2015, 250, 15-28. [CrossRef]

13. Best, J.L. Sediment transport and bed morphology at river channel confluences. Sedimentology 1988, 35, 481-498. [CrossRef]

14. Ribeiro, M.L.; Blanckaert, K.; Roy, A.G.; Schleiss, A.J. Flow and sediment dynamics in channel confluences. J. Geophys. Res. Earth Surf. 2012, 117. [CrossRef]

15. Boyer, C.; Roy, A.G.; Best, J.L. Dynamics of a river channel confluence with discordant beds: Flow turbulence, bed load sediment transport, and bed morphology. J. Geophys. Res. Earth Surf. 2006, 111. [CrossRef]

16. de Morais, E.S.; dos Santos, M.L.; Cremon, E.H.; Stevaux, J.C. Floodplain evolution in a confluence zone: Parana and ivai rivers, brazil. Geomorphology 2016, 257, 1-9. [CrossRef]

17. Dixon, S.J.; Sambrook Smith, G.H.; Best, J.L.; Nicholas, A.P.; Bull, J.M.; Vardy, M.E.; Sarker, M.H.; Goodbred, S. The planform mobility of river channel confluences: Insights from analysis of remotely sensed imagery. Earth-Sci. Rev. 2018, 176, 1-18. [CrossRef]

18. Ashmore, P.E. Laboratory modelling of gravel braided stream morphology. Earth Surf. Process. Landf. 1982, 7, 201-225. [CrossRef]

19. Ashworth, P.J. Mid-channel bar growth and its relationship to local flow strength and direction. Earth Surf. Process. Landf. 1996, 21, 103-123. [CrossRef]

20. Ashworth, P.J.; Ferguson, R.I.; Powell, M.D. Bedload Transport and Sorting in Braided Channels; John Wiley \& Sons: New York, NY, USA, 1992; pp. 497-515.

21. McLelland, S.J.; Ashworth, P.J.; Best, J.L. The Origin and Downstream Development of Coherent Flow Structures at Channel Junctions; John Wiley and Sons: Hoboken, NJ, USA, 1996; pp. 459-490.

22. Lach, J.; Wyzga, B. Channel incision and flow increase of the upper wisloka river, southern poland, subsequent to the reafforestation of its catchment. Earth Surf. Process. Landf. 2002, 27, 445-462. [CrossRef]

23. Kondolf, G.M. Hungry water: Effects of dams and gravel mining on river channels. Environ. Manag. 1997, 21, 533-551. [CrossRef]

24. Petts, G.E.; Gurnell, A.M. Dams and geomorphology: Research progress and future directions. Geomorphology 2005, 71, 27-47. [CrossRef]

25. Yang, S.L.; Zhang, J.; Xu, X.J. Influence of the three gorges dam on downstream delivery of sediment and its environmental implications, yangtze river. Geophys. Res. Lett. 2007, 34, 10. [CrossRef]

26. Chen, Z.Y.; Wang, Z.H.; Finlayson, B.; Chen, J.; Yin, D.W. Implications of flow control by the three gorges dam on sediment and channel dynamics of the middle yangtze (changjiang) river, china. Geology 2010, 38, 1043-1046. [CrossRef]

27. Everitt, B. Channel responses to declining flow on the rio-grande between $\mathrm{ft}$ quitman and presidio, texas. Geomorphology 1993, 6, 225-242. [CrossRef]

28. Pizzuto, J.E. Channel adjustments to changing discharges, powder river, montana. Geol. Soc. Am. Bull. 1994, 106, 1494-1501. [CrossRef] 
29. Latimer, R.A.; Schweizer, C.W. The Atchafalaya River Study; A Report Based Upon Engineering and Geological Studies of the Enlargement of Old and Atchafalaya Rivers; Army Corps of Engineers, Mississippi River Commission: Vicksburg, MS, USA, 1951.

30. Mossa, J. The changing geomorphology of the Atchafalaya River, Louisiana: A historical perspective. Geomorphology 2016, 252, 112-127. [CrossRef]

31. Rosen, T.; Xu, Y.J. Estimation of sedimentation rates in the distributary basin of the mississippi river, the atchafalaya river basin, USA. Hydrol. Res. 2015, 46, 244-257. [CrossRef]

32. $\mathrm{Xu}, \mathrm{Y} . J$. Long-term sediment transport and delivery of the largest distributary of the mississippi river, the atchafalaya, USA. IAHS AISH Publ. 2010, 337, 282-290.

33. Fisk, H.N. Geological Investigation of the Atchafalaya Basin and the Problem of Mississippi River Diversion; Wterways Experiment Station: Vicksburg, MS, USA, 1952; p. 145.

34. Mossa, J. Historical changes of a major juncture: Lower old river, louisiana. Phys. Geogr. 2013, 34, 315-334. [CrossRef]

35. Mize, S.V.; Murphy, J.C.; Diehl, T.H.; Demcheck, D.K. Suspended-sediment concentrations and loads in the lower mississippi and atchafalaya rivers decreased by half between 1980 and 2015. J. Hydrol. 2018, 564, 1-11. [CrossRef]

36. Wang, B.; Xu, Y.J. Decadal-scale riverbed deformation and sand budget of the last $500 \mathrm{~km}$ of the mississippi river: Insights into natural and river engineering effects on a large alluvial river. J. Geophys. Res. Earth Surf. 2018, 123, 874-890. [CrossRef]

37. Galler, J.J.; Bianchi, T.S.; Alison, M.A.; Wysocki, L.A.; Campanella, R. Biogeochemical implications of levee confinement in the lowermost mississippi river. EosTrans. Am. Geophys. Union 2003, 84, 469-476. [CrossRef]

38. Wu, C.-Y.; Mossa, J.; Mao, L.; Almulla, M. Comparison of different spatial interpolation methods for historical hydrographic data of the lowermost mississippi river. Ann. GIS 2019, 25, 133-151. [CrossRef]

39. Wheaton, J.M.; Brasington, J.; Darby, S.E.; Kasprak, A.; Sear, D.; Vericat, D. Morphodynamic signatures of braiding mechanisms as expressed through change in sediment storage in a gravel-bed river. J. Geophys. Res. Earth Surf. 2013, 118, 759-779. [CrossRef]

40. Wheaton, J.M.; Brasington, J.; Darby, S.E.; Sear, D.A. Accounting for uncertainty in dems from repeat topographic surveys: Improved sediment budgets. Earth Surf. Process. Landf. 2010, 35, 136-156. [CrossRef]

41. Julien, P.Y. Erosion and Sedimentation; Cambridge University Press: Cambridge, UK, 1995.

42. Rosen, T.; Xu, Y.J. A hydrograph-based sediment availability assessment: Implications for mississippi river sediment diversion. Water 2014, 6, 564-583. [CrossRef]

43. Schumm, S.A. River Variability and Complexity; Cambridge University Press: Cambridge, UK, 2005.

44. Wang, B.; Xu, Y.J. Estimating bed material fluxes upstream and downstream of a controlled large bifurcation-The mississippi-atchafalaya river diversion. Hydrol. Process. 2020. [CrossRef]

45. Couvillion, B.R.; Barras, J.A.; Steyer, G.D.; Sleavin, W.; Fischer, M.; Beck, H.; Trahan, N.; Griffin, B.; Heckman, D. Land Area Change in Coastal Louisiana from 1932 to 2010: U.S. Geological Survey Scientific Investigations Map 3164; USGS: Reston, VA, USA, 2011; p. 12.

46. Rouse, L.J., Jr.; Roberts, H.H.; Cunningham, R.H.W. Satellite observation of the subaerial growth of the atchafalaya delta, louisiana. Geology 1978, 6, 405-408. [CrossRef]

47. Rosen, T.; Xu, Y.J. Recent decadal growth of the atchafalaya river delta complex: Effects of variable riverine sediment input and vegetation succession. Geomorphology 2013, 194, 108-120. [CrossRef]

48. Barras, J.A. Land Area Change in Coastal Louisiana after the 2005 Hurricanes-A Series of Three Maps: U.S. Geological Survey Open-File Report 06-1274; US Department of the Interior: Washington, DC, USA, 2006.

49. Farris, G.S.; Smith, G.J.; Crane, M.P.; Demas, C.R.; Robbins, L.L.; Lavoie, D.L. (Eds.) Science and the Storms-The Usgs Response to the Hurricanes of 2005: U.S. Geological Survey Circular 1306; USGS: Reston, VA, USA, 2007; p. 283.

50. Walker, N.D. Tropical storm and hurricane wind effects on water level, salinity, and sediment transport in the river-influenced atchafalaya-vermilion bay system, louisiana, USA. Estuaries 2001, 24, 498-508. [CrossRef]

51. Johnson, W.B.; Sasser, C.E.; Gosselink, J.G. Succession of vegetation in an evolving river delta, atchafalaya bay, louisiana. J. Ecol. 1985, 73, 973-986. [CrossRef]

52. Carle, M.V.; Sasser, C.E.; Roberts, H.H. Accretion and vegetation community change in the wax lake delta following the historic 2011 mississippi river flood. J. Coast. Res. 2015, 31, 569-587. [CrossRef] 
53. Roberts, H.H.; Coleman, J.M.; Bentley, S.J.; Walker, N. An embryonic major delta lobe; a new generation of delta studies in the atchafalaya-wax lake delta system. Trans. Gulf Coast Assoc. Geol. Soc. 2003, 53, 690-703.

54. Nittrouer, J.A.; Shaw, J.; Lamb, M.P.; Mohrig, D. Spatial and temporal trends for water-flow velocity and bed-material sediment transport in the lower mississippi river. Geol. Soc. Am. Bull. 2012, 124, 400-414. [CrossRef]

55. Lamb, M.P.; Nittrouer, J.A.; Mohrig, D.; Shaw, J. Backwater and river plume controls on scour upstream of river mouths: Implications for fluvio-deltaic morphodynamics. J. Geophys. Res. Earth Surf. 2012, 117, 15. [CrossRef]

56. Chatanantavet, P.; Lamb, M.P.; Nittrouer, J.A. Backwater controls of avulsion location on deltas. Geophys. Res. Lett. 2012, 39, L01402. [CrossRef]

57. Deltares. Delft3d-Flow Simulation of Multi-Dimensional Hydrodynamic Flows and Transport Phenomena, Including Sediments User Manual; Deltares: Delft, The Netherlands, 2020.

58. Berger, R.C.; Tate, J.N.; Brown, G.L.; Savant, G. Guidelines for Solving Two Dimensional Shallow Water Problems with the Adaptive Hydraulics (ADH) Modeling System; U.S. Army Corps of Engineers, Engineering Research and Development Center: Vicksburg, MS, USA, 2010.

(C) 2020 by the authors. Licensee MDPI, Basel, Switzerland. This article is an open access article distributed under the terms and conditions of the Creative Commons Attribution (CC BY) license (http://creativecommons.org/licenses/by/4.0/). 